\title{
（294）第一水銀塩を還元剂として用いる容量法 第二鉄および第二銅イオンの定量——
}

(昭 和 30 年 6 月 10 日受理)

松尾 力*

第一水銀塩を還元剤として用いる容量法については Belcher 一門1)の報告がある。著者は第一水銀塩を用いる容量分析法の研 究の一連のテーマとして本題をとり上げ, $\mathrm{Fe}^{3+}$ および $\mathrm{Cu}^{2+}$ の 定量条件を吟味してみた。

\section{使用した試楽}

$\mathrm{Hg}_{2}{ }^{2+}$ 溶液 ${ }^{2)}: \mathrm{Hg}_{2}\left(\mathrm{NO}_{3}\right)_{2} \cdot 2 \mathrm{H}_{2} \mathrm{O}$ を用い $\mathrm{N} / 40$ お゙よび $\mathrm{N} / 100$ 溶液を調製し，金属水銀を共存させて保存 $\left(\mathrm{HNO}_{3}\right.$ 微酸酸性)。 標定は $\mathrm{KBr}$ 溶液で行い, 指示薬としてヨードフェノールブルー を用いた。

$\mathrm{Fe}^{3+}$ 溶液: $\mathrm{Fe}\left(\mathrm{NO}_{3}\right)_{3} \cdot 9 \mathrm{H}_{2} \mathrm{O}$ を用い $\mathrm{Fe}^{3+}$ として $10 \mathrm{mg} / \mathrm{ml}$ 溶液を調彆し，その含量は重量法により求めた $\left(\mathrm{Fe}\left(\mathrm{NO}_{3}\right)_{3} \cdot 9 \mathrm{H}_{2} \mathrm{O}\right.$ $\left.73 \mathrm{~g}+4.5 \mathrm{~N}-\mathrm{HNO}_{3} 200 \mathrm{~m} l / l\right)$ 。この溶液をらすめて $\mathrm{Fe}^{3+} 0.5 \mathrm{mg} /$ $\mathrm{m} l$. 特よび $0.1 \mathrm{mg} / \mathrm{m} l$ 溶液を調製した。

$\mathrm{Cu}^{2+}$ 溶液: $\mathrm{CuSO}_{4} \cdot 5 \mathrm{H}_{2} \mathrm{O}$ を用い $\mathrm{Cu}^{2+}$ として $10 \mathrm{mg} / \mathrm{ml}$ 溶液 を調彆し，その含量はヨード法により求めた $\left(\mathrm{CuSO}_{4} \cdot 5 \mathrm{H}_{2} \mathrm{O} 37 \mathrm{~g}\right.$ $\left.+18 \mathrm{~N}-\mathrm{H}_{2} \mathrm{SO}_{4} 6 \mathrm{ml} / \mathrm{l}\right)$ 。この溶液をうすめて $\mathrm{Cu}^{2+}, 2 \mathrm{mg} / \mathrm{ml}$ 拉 よび $1 \mathrm{mg} / \mathrm{m} l$ 溶液を調製した。

$\mathrm{SCN}^{-}$溶液：KSCN を用いて次の 4 種の溶液を調彆した。 $\mathrm{SCN}^{-}$として 10，50，100 および $200 \mathrm{mg} / \mathrm{ml}$ (それぞれの濃度 は $0.17,0.85,1.7$ および $3.4 \mathrm{M}$ )。

$\mathrm{HNO}_{3}: 1.8 \mathrm{~N}(10 \%)$ および $4.5 \mathrm{~N}(25 \%) 。$

オルトジアニシジン溶液：オルトジアニシジン (ODA と記す) $1 \mathrm{~g}$ 水酢酸 $2 \mathrm{~m} l$ 加えて可溶性醀酸塩とし, 水を $100 \mathrm{ml}$ 加え た。

$\mathrm{Fe}^{2+}$ 溶液 $: \mathrm{FeSO}_{4} \cdot\left(\mathrm{NH}_{4}\right)_{2} \mathrm{SO}_{4} \cdot 6 \mathrm{H}_{2} \mathrm{O}$ を用い, $\mathrm{M} / 10$ 溶液 (0.1 $\mathrm{N}-\mathrm{H}_{2} \mathrm{SO}_{4}$ 酸性)を調彆した。市肘特級品といえども $\mathrm{Fe}^{3+}$ が微量 含をれているから使用のつど $\mathrm{Fe}^{3+}$ 含量を以下に述べる方法によ り求めて実験値を補正した（第 3 図参照）。

\section{（I）第二鉄イオンの定量}

第一水銀塩による $\mathrm{Fe}^{3+}$ の容量は Belcher ${ }^{1)}$ の報文のほかに二, 三3) みられる。まず $\mathrm{Hg}_{2}{ }^{2+} / \mathrm{Hg}^{2+}$ 系と $\mathrm{Fe}^{2+} / \mathrm{Fe}^{3+}$ 系の標準電極 電位から還元反応を考察してみた（数値はLatimer ${ }^{4}$ のものを使 用)。

$\log K=\frac{n}{0.059}\left(E_{0}-E^{\prime}{ }_{0}\right) \mathrm{Hg}_{2}{ }^{2+} \rightleftharpoons 2 \mathrm{Hg}^{2+}+2 \mathrm{e} \quad E_{0}=-0.910 \mathrm{~V}$

* 山形大学文理学部 : 山形市.

1) R. Belcher, T.S. West, Anal. Chim. Acta 5, 260, 268, 360, 364, 472, 474, 546 (1951), 7, 470 (1952).

2) 松尾, 工化 56, 70 (1953).

3) H. Flaschka, Mikrochemie ver. Mikrochim. Acta 35, 473 (1950); F. Burriel, F. Lucena Conde; Anal. Chem. 26, 88 (1954) に引用されている.

4) W. M. Latimer, "Oxidation Ratentials" p. 213 ; $\mathrm{Cu}^{2+}$ に関しては p. 170 (1938) (Prentice Hall, New York.)

$$
\begin{gathered}
\mathrm{Fe}^{2+} \rightleftharpoons \mathrm{Fe}^{3+}+\mathrm{e}-E_{0}{ }^{\prime}=-0.771 \mathrm{~V} \\
\mathrm{Hg}_{2}{ }^{2+}+2 \mathrm{Fe}^{3+} \rightleftharpoons 2 \mathrm{Hg}^{2+}+2 \mathrm{Fe}^{2+} \\
\log K_{\mathrm{A}}=\frac{2}{0.059}(-0.910+0.771) \quad K_{\mathrm{A}}=1.95 \times 10^{-5}
\end{gathered}
$$

上の数值から $\mathrm{Hg}_{2}{ }^{2+}$ による $\mathrm{Fe}^{2+}$ の還元が進むるのと理解され る。この還元反応を容量法に適用するために指示薬として深赤色 の第二鉄ーチオシアン錯塩 $\left(\left[\mathrm{Fe}(\mathrm{SCN})_{6}\right]_{n}{ }^{n-3}\right)$ を用いた。

この第二鉄ーチオシアン錯塩を生成させるために $\mathrm{SCN}$-を共存 させれば平衡定数 $\left(K_{\mathrm{C}}\right)$ は $K_{\mathrm{A}}$ よりさらに小さくなるので還元 反応は定量的に進行するるのと考えられる。

$$
\begin{aligned}
& {\left[\mathrm{Fe}(\mathrm{SCN})_{6}\right]^{3-} \rightleftharpoons\left[\mathrm{Fe}(\mathrm{SCN})_{3}\right]+3 \mathrm{SCN}^{-}} \\
& K_{1}=3.1 \times 10^{-4} \\
& {\left[\mathrm{Fe}(\mathrm{SCN})_{3}\right] \rightleftharpoons \mathrm{Fe}^{3+}+3 \mathrm{SCN}^{-}} \\
& K_{2}=2.6 \times 10^{-6} \\
& \text { よって }\left[\mathrm{Fe}(\mathrm{SCN})_{6}\right]^{3-} \rightleftharpoons \mathrm{Fe}^{3+}+6 \mathrm{SCN}^{-} \\
& K_{3}=K_{1} \times K_{2}=8 \times 10^{-10}
\end{aligned}
$$

$\mathrm{Hg}_{2}{ }^{2+}+2\left[\mathrm{Fe}(\mathrm{SCN})_{6}\right]^{3-} \rightleftharpoons 2 \mathrm{Fe}^{2+}+2 \mathrm{Hg}^{2+}+12 \mathrm{SCN}^{-}$

$$
K_{\mathrm{B}}=K_{3}{ }^{2} \cdot K_{\mathrm{A}}=\left(8 \times 10^{-10}\right)^{2} \cdot 1.95 \times 10^{-5}=1.25 \times 10^{-23}
$$

(B) の反応において $\mathrm{Hg}^{2+}$ と $\mathrm{SCN}^{-}$とから $\left[\mathrm{Hg}(\mathrm{SCN})_{4}\right]^{2-}$ の 生成が考えられる。

$$
\begin{aligned}
\mathrm{Hg}^{2+}+4 \mathrm{SCN}^{-} \rightleftharpoons & {\left[\mathrm{Hg}(\mathrm{SCN})_{4}\right]^{2-} } \\
\left.K_{4}=1 \times 10^{-225}\right) &
\end{aligned}
$$

（B）式を次のように書きかえると

$$
\begin{gathered}
\mathrm{Hg}_{2}{ }^{2+}+2\left[\mathrm{Fe}(\mathrm{SCN})_{6}\right]^{3-} \rightleftharpoons \\
2 \mathrm{Fe}^{2+}+2\left[\mathrm{Hg}(\mathrm{SCN})_{4}\right]^{2-}+4 \mathrm{SCN}- \\
K \mathrm{C}=K_{4}{ }^{2} / K_{\mathrm{B}}=\left(1 \times 10^{-22}\right)^{2} / 1.25 \times 10^{-23}=8 \times 10^{-22}
\end{gathered}
$$

\section{実 験}

$\mathrm{Fe}^{3+}$ 検液をホー゙ルピペット $(20$ または $10 \mathrm{ml})$ で採取し, 一 定量の $\mathrm{KSCN}, \mathrm{HNO}_{3}$ 溶液を加光全容を約 $50 \mathrm{ml}$ とする。 $\mathrm{Fe}^{3+}$ は $\left[\mathrm{Fe}(\mathrm{SCN})_{6}\right] n_{n}^{n-3}$ を生成し濃血赤色を呈する。よくかきまぜ ながら $\mathrm{Hg}_{2}{ }^{2+}$ 溶液を徐々に滴加し(終点付近ではとくに徐々に加 える)，裉色したところを滴定終点とする。なお本実験では $5 \mathrm{ml}$ (1/50 目盛) または $10 \mathrm{ml}(1 / 20$ 目盛) ビュレットを使用した。 $\mathrm{N} / 100-\mathrm{Hg}_{2}{ }^{2+} 1 \mathrm{ml} \equiv 0.5585 \mathrm{mgFe}^{3+}$ 。

\section{実㩆結果と考案}

第二鉄-チオシアン錯塩の呈色は $\mathrm{Fe}^{3+}$ の比色定量に利用され, その比色条件については多数の報文 ${ }^{6)}$ がある。この錯塩の安定度 は SCN- 濃度, 酸性度によって異なることが報告されている。 本実験に拈いては $\mathrm{SCN}^{-}$濃度を $\mathrm{Fe}^{3+} / \mathrm{SCN}-$ モル比で示し, 酸 性度は $\mathrm{HNO}_{3}$ 濃度 (N) で示した。第 1 および 2 函に SCN- 濃

5) I. M. Kolthoff, N. H. Furman, "Potentiometric Titrations"' p. 332 (1926).

6) E.B. Sandell, "Colorimetric determination of traces of metals”p. 130 (1950) に集録されている. 
度, $\mathrm{HNO}_{3}$ 酸性度および放置時間の影簌を示した。

第 1 四に示した実験值はそれぞれの試薬添加後 3 分経過してか ら滴定した結果であるが, $\mathrm{HNO}_{3}$ 酸性度が $0.4 \mathrm{~N}$ 以上になると 錯塩が安定化されるためであろ5 $\mathrm{Hg}_{2}{ }^{2+}$ による還元が定量的に 進行せず過大な值を示し, 滴定により袙色した溶液は漸次復色し てくる。第 2 図には錯塩生成後の放置時間の影響を示した。錯塩 生成後 3 分経過してから滴定する時には満足な結果を与える酸性 度でも，30 分経過してから滴定する時には過大な結果を与え， ことに SCN- 濃度が大となれば (C) 式の僈元反応は認められ ない。また酸性度が低い時 $(0.025 \mathrm{~N})$ には過小な結果を示す。 $\mathrm{Fe}^{3+} / \mathrm{SCN}^{-}$モル比は 50〜500 の範囲において満足な結果を与え るが, モル比が 50 以下の場合には褪色が早く起り白濁する。こ の事実は有機溶媒に対する抽出性の実験結果をあわせ考えて次の ように考えた。（C）式に示した第二鉄ーチオ.シアン錯塩の組成は 一定でなく，一部分は還元されるが，一部分は $\mathrm{Hg}_{2}{ }^{2+}$ による還元 をうけないで $\mathrm{Hg}_{2}{ }^{2+}$ は共存する $\mathrm{SCN}^{-}$と $\mathrm{Hg}_{2}(\mathrm{SCN})_{2}$ を生成 して白濁する。 $\mathrm{Fe}(\mathrm{SCN})_{3}+\mathrm{Hg}_{2}{ }^{2+} \rightarrow \mathrm{FeSCN}+\mathrm{Hg}_{2}(\mathrm{SCN})_{2}$

\section{第二鉄-チオシアン錯塭の有機溶媒に対する抽出定性的試硂}

$\mathrm{Fe}^{3+} 100 \gamma$ 用い $\mathrm{Fe}^{3+} / \mathrm{SCN}-$ モル比 $1: 5 \sim 50$ 範囲において 生成した皇色をイソブチルアルコールトエーテル (2:1 (容量)) 溶媒炕て抽出したところ $\mathrm{Fe}^{3+} / \mathrm{SCN}$ - モル比の大きい時には抽出 能は大となり, 同一モル此の場合 $\mathrm{HNO}_{3}$ 酸性度が高くなると抽 出能は小さくなる。モル比 10 の場合汇はほとんど抽出されない。 $\mathrm{SCN}^{-}$濃度が小さい時には $\mathrm{FeSCN}^{2+}$ 等の錯塩が生成するとい ら三, 三の報文 ${ }^{7)}$ がある。

第1表に $\mathrm{Fe}^{3+}$ 1〜10 mg の定量結果を示した。 $\mathrm{Fe}^{3+}$ 含量が 多い場合には生成した錯塩を長く放着する時飞は正誤差を示す。

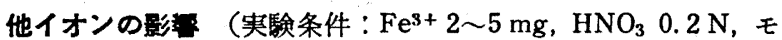
ル比 $200 \mathrm{KSCN} 0.35 \mathrm{M}$ )。

$\mathrm{Na}^{+}, \mathrm{K}^{+}, \mathrm{NH}_{4}^{+}, \mathrm{Mg}^{2+}, \mathrm{Ca}^{2+}, \mathrm{Ba}^{2+}, \mathrm{Zn}^{2+}, \mathrm{Cd}^{2+}, \mathrm{Al}^{3+}$ $\mathrm{NO}_{3}{ }^{-}, \mathrm{Cl}^{-}, \mathrm{SO}_{4}{ }^{2-}, \mathrm{AcO}^{-}$は $500 \mathrm{mg}$ の共存はさしつかえない。 $\mathrm{Zn}^{2+}$ が共存する時には $\mathrm{Zn}\left[\mathrm{Hg}(\mathrm{SCN})_{4}\right]$ の白沈が生成するが， 滴定終点に影響は与えない。 $\mathrm{Mn}^{2+}(250), \mathrm{Ni}^{2+}(20), \mathrm{Co}^{2+} お$ よ び $\mathrm{Cu}^{2+}$ が共存する時にはあらかじめ除去して招かなければなら ない。 $\mathrm{Fe}^{3+}$ と可溶性錯塩を生成する $\mathrm{PO}_{4}{ }^{3-}, \mathrm{F}^{-}$, 酒石酸塩, クエ

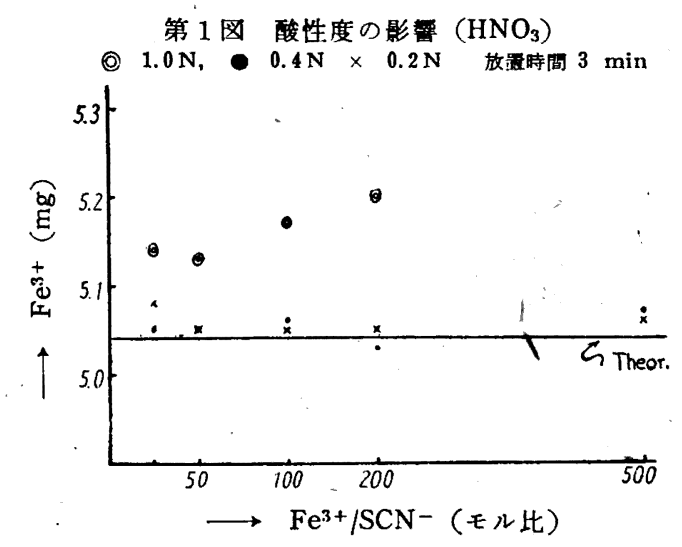

第 2 図酸性度および放置時間の影䈏
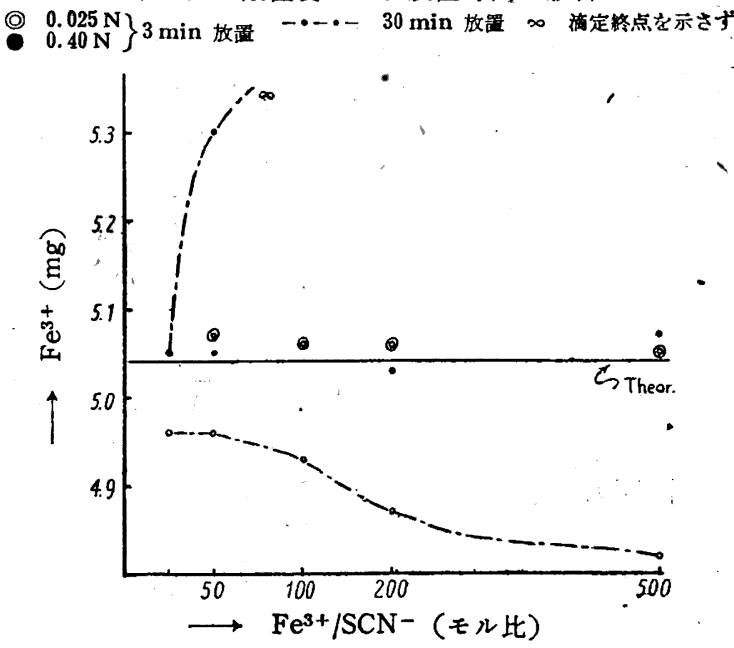

ン酸塩, $\mathrm{C}_{2} \mathrm{O}_{4}^{2}$ 等が共存すればチオシアン錯塩の生成を妨害する と考えられるが, 本実験の定量条件の酸性溶夜 $\left(\mathrm{HNO}_{3}: 0.2 \mathrm{~N}\right)$ では次に示す範囲内であれば共存はさしつかえない。酒石酸塩, クエン酸塩, $\mathrm{PO}_{4}{ }^{3-}(500), \mathrm{C}_{2} \mathrm{O}_{4}{ }^{2-}(50), \mathrm{P}_{2} \mathrm{O}_{7}{ }^{4-}$ および $\mathrm{F}^{-}(25)$ 。 ( ) は共存可能な $\mathrm{mg}_{\text {。 }}$

7) H. S. Frank, R. L. Oswalt, J. Am. Chem. Soc. 69, 1321 (1947); 額田, 日化 64, 669 (1943); 内海, 日化 73, 840 (1952)

定量（その 1)

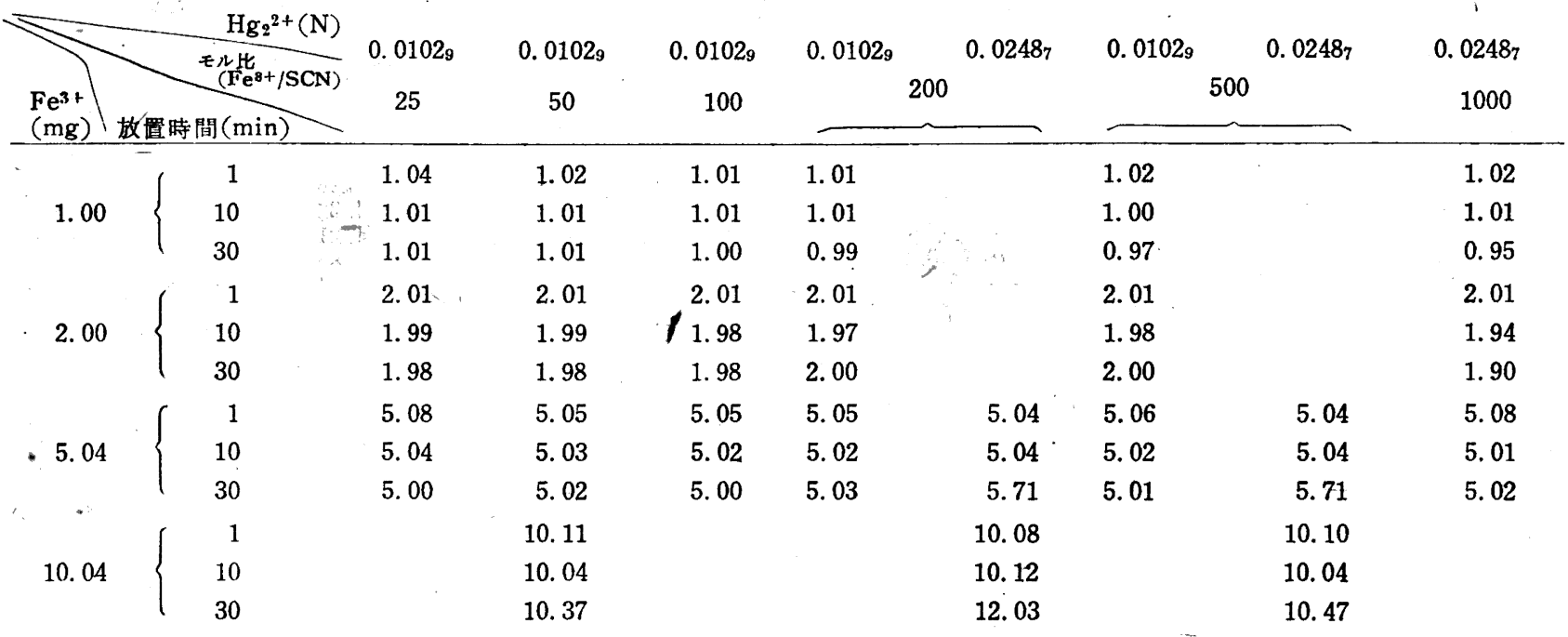


第 2 表に $\mathrm{Fe}^{3+}$ 1 10 $\mathrm{mg}$ の定量結果（その 2) を示し，第 3 表に二, 三の応用例を示した。

第 2 表 $\mathrm{Fe}^{3+}$ の定量 (その 2 )

\begin{tabular}{|c|c|c|c|c|c|}
\hline \multirow{2}{*}{ No. } & \multicolumn{2}{|c|}{$\mathrm{Hg}_{2}{ }^{2+}$ 溶液 } & \multicolumn{3}{|c|}{$\mathrm{Fe}^{3+}(\mathrm{mg})$} \\
\hline & 濃度 $(\mathrm{N})$ & 消費量 $(\mathrm{ml})$ & 理論值 & 実験值 & 誤差 \\
\hline 1 & 0.01029 & $1.79_{0}$ & 1.00 & 1.01 & +0.01 \\
\hline 2 & $0.0101_{6}$ & $3.49_{5}$ & 2.00 & 1.98 & -0.02 \\
\hline 3 & 0.01029 & 8.73 & 5.04 & 5.02 & -0.02 \\
\hline 4 & 0.02487 & $3.64_{0}$ & $\prime \prime$ & 5.04 & 0 \\
\hline 5 & $" \prime$ & 7.26 & 10.04 & 10.08 & +0.0 \\
\hline
\end{tabular}

$\mathrm{HNO}_{3}: 0.2 \sim 0.4 \mathrm{~N}, \mathrm{Fe}^{3+} / \mathrm{SCN}-25 \sim 500$, 試薬添加後 10 分以内

(I) 試薬中の徽量鉄の定量

$$
\text { 第 } 3 \text { 㤗 }
$$

(1) 硝酸アルミニウム ( 1 䄲品)

$$
\mathrm{Al}\left(\mathrm{NO}_{3}\right)_{3} .9 \mathrm{H}_{2} \mathrm{O} \quad 35 \mathrm{~g} / 100 \mathrm{ml} \quad \mathrm{Fe}^{3+}: 0.004 \%
$$

\begin{tabular}{ccccc} 
& $\begin{array}{c}\mathrm{Fe}^{3+} \\
\text { (添量 } \\
(\mathrm{mg})\end{array}$ & $\begin{array}{c}0.0102 \mathrm{~s} \\
\mathrm{Hg}_{2}^{2+} \text { 消 } \\
\text { 費量 }(\mathrm{ml})\end{array}$ & $\begin{array}{c}\mathrm{Fe}^{3+} \\
(\mathrm{mg})\end{array}$ & $\begin{array}{c}\text { 検液 } 10 \mathrm{ml} \\
\text { 中心 } \mathrm{Fe}^{3+} \\
(\mathrm{mg})\end{array}$ \\
\hline 10.00 & 2.00 & 3.72 & 2.14 & $0.14_{0}$ \\
20.00 & $\prime$ & 3.95 & 2.27 & $0.13_{5}$ \\
10.00 & - & $0.24_{0}$ & 0.14 & $0.14_{0}$ \\
20.00 & 5.04 & $9.55^{*}$ & 5.25 & $0.10_{5}$
\end{tabular}

* 0.0098 $\mathrm{N} \mathrm{Hg}_{2}{ }^{2+}$ 。標準列法による比色值（キオシアン錯塩

法) $0.12 \mathrm{mg} /$ 検液 $10 \mathrm{ml}$

(2) モール氏塩 (特梌) $\mathrm{FeSO}_{4} \cdot\left(\mathrm{NH}_{4}\right)_{2} \mathrm{SO}_{4} \cdot 6 \mathrm{H}_{2} \mathrm{O}$ $9.802 \mathrm{~g} / 250 \mathrm{ml} \quad \mathrm{Fe}^{3+}: 0.04_{3} \%$ 検液 $10.00 \mathrm{ml}$ $0.0103_{8} \mathrm{~N} \mathrm{Hg}_{2}{ }^{2+}$ 消費量 $0.30_{0} \mathrm{ml} \mathrm{Fe} \mathrm{Fe}^{3+} 0.17 \mathrm{mg}$ この塩を溶解する時には $\mathrm{H}_{2} \mathrm{SO}_{4}$ 酸性にしてのち加温溶解する。 保存中にみられる酸化経過は第 3 図参照。

（II）温泉水中の全鉄の定量

試水: 藏王温泉类 (山形県南村山郡) $43.3^{\circ} \mathrm{C}, \mathrm{pH} 1.3$, 蒸発残椬 $3.489 \mathrm{~g} / \mathrm{kg}$ お。な共存イオン $\mathrm{Ca}^{2+}, \mathrm{Mg}^{2+}, \mathrm{Al}^{3+}, \mathrm{Cl}^{-}$, $\mathrm{SO}_{4}{ }^{2-}$ 試水 $100 \mathrm{ml}+$ conc. $\mathrm{HCl} 5 \mathrm{ml}+0.2 \mathrm{~g} \mathrm{KClO} \rightarrow$ 就固, 口别 $\rightarrow 100 \mathrm{ml}$ にうすめる。

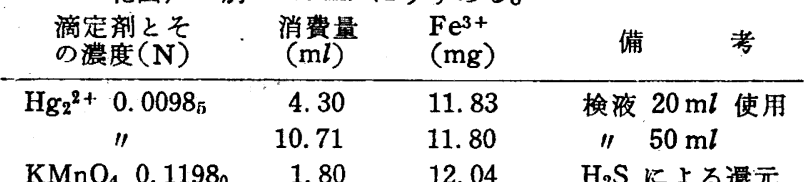

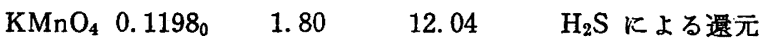
9.49 山形県薬務課分析值 採水月日不詳, 定量值の相違は試水放䁂中の変化と思われる。 ※ 山形県薬務課より供与されたるの。

\section{（II）第二銅イオンの定量}

$\mathrm{Cu}^{+} / \mathrm{Cu}^{2+}$ 系と $\mathrm{Hg}_{2}{ }^{2+} / \mathrm{Hg}^{2+}$ 系の橪準電極電位から $\mathrm{Hg}_{2}{ }^{2+}$ に よる $\mathrm{Cu}^{2+}$ の還元反応を考察してみた。

$$
\begin{aligned}
& \mathrm{Hg}_{2}{ }^{2+}+2 \mathrm{Cu}^{2+} \rightleftharpoons 2 \mathrm{Hg}^{2+}+2 \mathrm{Cu}^{+} \\
& \mathrm{Cu}^{+} \rightleftharpoons \mathrm{Cu}^{2+}+\mathrm{e} \\
& E_{0}^{\prime}=-0.167 \mathrm{~V} \quad \log K_{1}=\frac{2}{0.059}(-0.910+0.167) \\
& K_{1}=6.3 \times 10^{-26}
\end{aligned}
$$

この数值からは $\mathrm{Cu}^{2+}$ の還元滴定が可能なはずであるが, 実際 には還元は認められない。すなわち一定量の $\mathrm{Cu}^{2}+$ 溶液汇濃度既 知の $\mathrm{Hg}_{2}{ }^{2+}$ 溶液の一定過剩量を添加し, $\mathrm{Br}^{-}$溶液で $\mathrm{Hg}_{2}{ }^{2+}$ 溶液 の過剩量を滴定してみた（指示薬：ヨードフェノールブルー）が䢩 元は認められなかった。還元の起らない一つの原因として $\mathrm{Cu}^{+}$ の浱度がきわめて小さいためであろらと考えられる。

$$
\begin{aligned}
2 \mathrm{Cu}^{+} & \rightleftharpoons \mathrm{Cu}^{2+}+\mathrm{Cu}^{-} \\
K_{2} & =1.03 \times 10^{-6} \text { 8) }
\end{aligned}
$$

$\mathrm{SCN}^{-}$を共存させれば $\mathrm{Cu}+$ は CuSCN を生成し，（1）式は 正の方向に進み還元が起るだ 5。 $\mathrm{SCaSCN}=4 \times 10^{-14}$ 。よって (3) 式が考えられる。

$$
\mathrm{Hg}_{2}{ }^{2+}+2 \mathrm{Cu}^{2+}+\mathrm{SCN}^{-} \longrightarrow 2 \mathrm{CuSCN}+2 \mathrm{Hg}^{2+}
$$

しかし(3)式の反応は $\mathrm{SCN}^{-}$濃度に左右されて, $\mathrm{SCN}^{-}$濃度 が大きい時には還元作用は定量的に進まず，黒色の析出物 $(\mathrm{Hg}$ の析出と思われる）がみられた。

$\mathrm{Hg}_{2}{ }^{2+}+\mathrm{Cu}^{2}+5 \mathrm{SCN}-\longrightarrow \mathrm{CuSCN}+\left[\mathrm{Hg}(\mathrm{SCN})_{4}\right]^{2-}+\mathrm{Hg}$ (4)

Belcher ${ }^{9)}$ は $\mathrm{Hg}_{2}{ }^{2+} に よ る \mathrm{Cu}^{2+}$ の還元定量に次のような間 接方法を用い，その反応をそれぞれの標準電極電位の数值から考 察した。

$$
\begin{gathered}
\mathrm{Cu}^{2+}+\mathrm{Fe}^{2+} \longrightarrow \mathrm{Cu}^{+}+\mathrm{Fe}^{3+} \\
\mathrm{Cu}^{2+}+\mathrm{Fe}^{2+}+\mathrm{SCN}-\longrightarrow \mathrm{CuSCN}+\mathrm{Fe}^{3+}
\end{gathered}
$$

$\mathrm{SCN}^{-}$-が過剩に共存すれば $\mathrm{Fe}^{3+}$ はチオシアン錯塩を生成す る。

$\mathrm{Cu}^{2+}+\mathrm{Fe}^{2+}+7 \mathrm{SCN}-\longrightarrow \mathrm{CuSCN}+\left[\mathrm{Fe}(\mathrm{SCN})_{6}\right] n^{n-3}$

この $\left[\mathrm{Fe}(\mathrm{SCN})_{6}\right]_{n}{ }^{n-3}$ を $\mathrm{Hg}_{2}{ }^{2+}$ で滴定して $\mathrm{Cu}^{2+}$ を間接的 に定量した。

\section{実. 験}

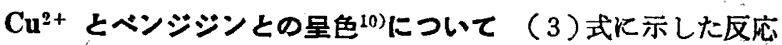
を用いて $\mathrm{Cu}^{2+}$ を滴定する際に指示薬として $\mathrm{Cu}^{2+}$ とヘンンジジン との呈色を利用した。C $\mathrm{Cu}^{2+}$ とベンジジンとの呈色は $\mathrm{SCN}$-の共 存によりはじめて鮮明となる。またベンジジンおよびその誘導体 と $\mathrm{Cu}^{2+}$ の呈色の鮮明度をくらべでみ。その誘導体としてオル トトリジン, オルトジアニシジンを用いたが, オルトジアニシジ ン $(\mathrm{ODA})^{11}$ 吊最も鮮明であることを認めた。

\begin{tabular}{|c|c|c|c|c|c|}
\hline \multirow[b]{2}{*}{ No. } & $\begin{array}{r}\text { 第 } 4 \text { 至 } \\
\mathrm{K}\end{array}$ & $\mathrm{Cu}^{2+}$ & \multirow{2}{*}{$\begin{array}{l}\text { 定量 (SCN } \\
0.01038 \mathrm{~N} \\
\mathrm{Hg}_{2}{ }^{2+} \\
\text { 消費量 } \\
\quad(\mathrm{ml})\end{array}$} & \multirow{2}{*}{$\begin{array}{l}\text { 好適瀼度 } \\
\mathrm{Cu}^{2+} \\
(\mathrm{mg})\end{array}$} & \multirow[b]{2}{*}{$\begin{array}{c}\text { 望 差 } \\
(\mathrm{mg})\end{array}$} \\
\hline & $\begin{array}{l}\text { 滛度 } \\
(\mathbf{M})\end{array}$ & $\begin{array}{c}\text { 添加量 } \\
(\mathrm{m} l)\end{array}$ & & & \\
\hline $\begin{array}{l}1 \\
2 \\
3 \\
4 \\
5\end{array}$ & $\begin{array}{l}0.5 \\
\prime \prime \\
1 " \\
1.0 \\
\prime \prime\end{array}$ & $\begin{array}{l}15 \\
20 \\
25 \\
15 \\
20\end{array}$ & $\begin{array}{l}14.45 \\
14.28 \\
14.32 \\
14.21 \\
13.85\end{array}$ & $\begin{array}{l}9.53 \\
9.42 \\
9.45 \\
9.37 \\
9.14\end{array}$ & $\begin{array}{l}+0.13 \\
+0.02 \\
+0.05 \\
-0.03 \\
-0.26\end{array}$ \\
\hline
\end{tabular}

$\mathrm{Cu}^{2+}$ とオルトジアニシジンとの量色 $\mathrm{Cu}^{2+} 0.1 \mathrm{mg}$ (全容 30 $\mathrm{m} l ; 1 \% \mathrm{ODA}$ 溶液 3 滴）は $\mathrm{KSCN} 0.2 \mathrm{M}$ 以上で淡青色を呈す る。この呈色は $\mathrm{pH} 4.4$ 以上で現われる。

滴定法：検液の一定量をホールピペットで採取し，一定量の $\mathrm{KSCN}$ 溶液を加え全容を約 $50 \mathrm{~m} l$ とする。これに $1 \%$ ODA 溶 液を 3 滴加え, 上くかきまぜながら $\mathrm{Hg}_{2}{ }^{2+}$ 溶液で滴定し, 谈青 色が裉色するところを滴定終点とした。な打本実験には $25 \mathrm{cc}$ (1/20 目盛) ビュレットを用いた。 $0.01 \mathrm{~N} \mathrm{Hg}^{2+} 1 \mathrm{ml}=0.635_{4}$ $\mathrm{mg} \mathrm{Cu} \mathrm{Cu}^{2+}$ 。

$\mathrm{SCN}-$ の好適濃度範囪：その結果の一部を第 4 表に示した。

この結果より SCN- 浱度範囲がこの還元反応を左右し; SCNが過大になると（No. 5) 黑色析出物がみられ滴定終点が早くみ られる (( 4 ) 式)。 $\mathrm{SCN}-$ 濃度を $0.25 \sim 0.4 \mathrm{M}$ に保って滴定し た結果を第 5 表に示した。

8) 石川総雄著：理諭無機化学各諭 p. 229 (1952)内田老隹埔.

s) R. Belcher, T.S. West, Anal. Chim. Acta 5, 364 (1951).

10) “Tables of Reagents for Inorganic Analysis" p. 27.

11) 松尾, 工化 57, 808 (1954). 


\begin{tabular}{|c|c|c|c|c|c|c|c|}
\hline \multirow{2}{*}{ No. } & \multirow{2}{*}{$\frac{\mathrm{Hg}_{\mathbf{g}^{2}+}}{(\mathrm{N})}$} & \multirow{2}{*}{  } & \multicolumn{2}{|c|}{$\begin{array}{l}\mathrm{Cu}^{2+} \\
\mathrm{KSCN}\end{array}$} & \multicolumn{2}{|c|}{$\begin{array}{l}\text { 定 量 } \\
\mathrm{Cu}^{2}+(\mathrm{mg})\end{array}$} & \multirow[b]{2}{*}{ 罟 } \\
\hline & & & (M) & 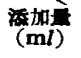 & 理䄖値 & 英续値 & \\
\hline 1 & $0.0103_{8}$ & 14.24 & 0.5 & 25 & 9.40 & 9.40 & 0 \\
\hline 2 & $"$ & 14.21 & 1.0 & 15 & " & 9.38 & -0.02 \\
\hline 3 & $"$ & 14.23 & 1.5 & 10 & " & 9.39 & -0.01 \\
\hline 4 & $0.0258_{b}$ & 5.80 & 1.0 & $n$ & $"$ & 9.51 & +0.11 \\
\hline 5 & $n$ & 5.82 & " & 15 & $n$ & 9.54 & +0.14 \\
\hline 6 & " & 5.79 & $"$ & 20 & " & 9.49 & +0.09 \\
\hline 7 & $"$ & 11.40 & 1.5 & 10 & 18.80 & 18.70 & -0.10 \\
\hline 8 & $0.0548_{2}$ & 5.39 & 1.0 & 15 & $" \prime$ & 18.75 & -0.05 \\
\hline 9 & $n$ & 5.40 & $n$ & 20 & $"$ & 18.79 & -0.01 \\
\hline 10 & $n$ & 13.51 . & $n$ & 15 & 47.00 & 47.01 & +0.01 \\
\hline
\end{tabular}

$\mathrm{Cu}^{2+} 10 \mathrm{mg}$. 以下の場合には, $\mathrm{Cu}^{2+}$ と ODA との呈色の裉色 が明膫でなく，定量が困難である。 $\mathrm{Cu}^{2+} 20 \mathrm{mg}$ 以上になると， $\mathrm{SCN}^{-}$の好適濃度篹囲は涨くなる (No. 10)。

Belcher 法の追試実駧 前述の Belcher 法による $\mathrm{Cu}^{2+}$ の定量 を試みた。一定量の $\mathrm{Cu}^{2+}$ 検液に $\mathrm{Fe}^{2+}$ 溶液 $\left(\mathrm{Fe}^{3+}\right.$ 含量をあら かじめ求めておく)を添加して $\mathrm{Cu}^{2+}$ を還元し，さらに KSCN, $\mathrm{HNO}_{3}$ 両溶液をそれぞれ加兄て $\mathrm{KSCN}$ として約 $0.2 \mathrm{~N}, \mathrm{HNO}_{3}$ として $0.2 \mathrm{~N}$ とする。 $\mathrm{Cu}^{2+}$ ，の還元のため消費された $\mathrm{Fe}^{2+}$ は $\mathrm{Fe}^{3+}$ となり $\left[\mathrm{Fe}(\mathrm{SCN})_{6}\right] n^{n-3}$ を生成する。この錯塩による深血 赤色が裉色するまで $\mathrm{Hg}_{2}{ }^{2+}$ 溶液に上り滴定した。その結果を第 6 表に示した。（I）に示したよ5に $\mathrm{Hg}_{2}{ }^{2+}$ 溶液による $\mathrm{Fe}^{3+}$ の滴定は $\mathrm{Fe}^{3+} 10 \mathrm{mg}$ 以下に批いて好結果を与克るから, 本法は $\mathrm{Cu}^{2+}$ として $10 \mathrm{mg}$ 以下の場合炕適する $\left(\mathrm{Fe}^{2+}: \mathrm{Cu}^{2+}\right.$ モル比 $=1: 1.14) 。 \mathrm{Fe}^{2+}$ 溶液の保存中にみられる酸化経過を第 3 四に 示した。

第 3 図第一鉄塩溶液の酸化経過

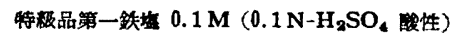

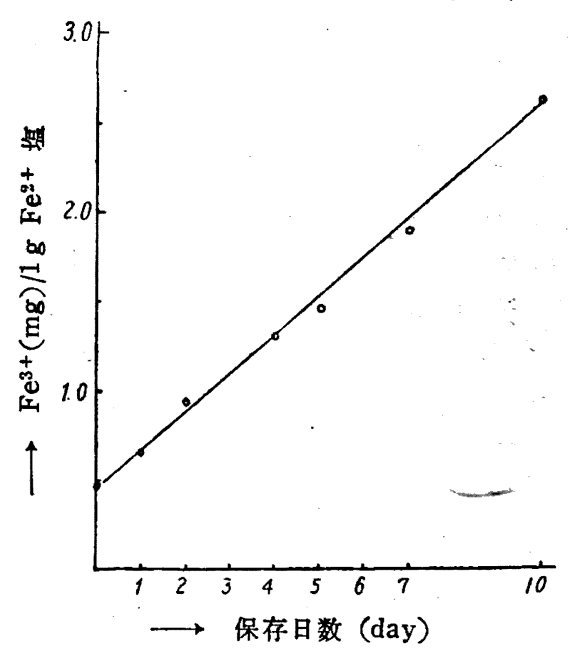

第6 表 $\mathrm{Cu}^{2+}$ の定量 (Belcher法)

\begin{tabular}{|c|c|c|c|c|c|c|}
\hline \multirow{2}{*}{ No. } & \multicolumn{2}{|c|}{$\mathrm{Hg}_{\mathbf{}^{2}}{ }^{2+}$ 涪液 } & \multirow{2}{*}{ 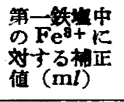 } & \multicolumn{3}{|c|}{$\mathrm{Cu}^{2+}(\mathbf{m g})$} \\
\hline & 滑度 $(\mathbf{N})$ & 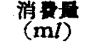 & & 理語值 & 実䠲値 & 諆 差 \\
\hline 1 & $0.0103_{8}$ & $1.63_{0}$ & 0.19 & $0.94_{0}-$ & $0.95_{0}$ & +0.010 \\
\hline 2 & $n$ & $3.64 \%$ & 0.12 & $2,35_{5}$ & $2.32_{8}$ & -0.03 \\
\hline 3 & " & $7.30^{\circ}$ & 0.19 & $4.70^{\circ}$ & 4.69 & -0.01 \\
\hline 4 & $"$ & 14.52 & 0.38 & 9.40 & 9.33 & -0.07 \\
\hline 5 & $0.0258_{b}$ & 5.99 & 0.24 & " & 9.43 & +0.03 \\
\hline 6 & $"$ & 11.91 & 0.45 & 18.80 & 18.79 & -0.01 \\
\hline 7 & $0.0548_{2}$ & 5.66 & 0.27 & " & 18.75 & -0.05 \\
\hline 8 & $"$ & 14.01 & 0.49 & 47.00 & 47.05 & +0.05 \\
\hline
\end{tabular}

緼括

第一水銀塩により $\mathrm{Fe}^{3+}$ および $\mathrm{Cu}^{2+}$ の還元定量を行った。 $\mathrm{Fe}^{3+}$ の定量。 $\mathrm{Fe}^{3+} 飞 \mathrm{SCN}^{-}$を共存させて第二鉄-チオシア ン錯塩を生成させる時には $\mathrm{Fe}^{3+}+\mathrm{Hg}_{2}{ }^{2+} \rightleftharpoons \mathrm{Fe}^{2+}+\mathrm{Hg}^{2+}$ の還元 反応の平衡定数は小さくなるばかりでなく，錯塩の呈色の襀色が 滴定終点を示すので好都合である。この錯塩は $\mathrm{HNO}_{3}$ 0.2 2 0.4 $\mathrm{N}, \mathrm{SCN}^{-}$濃度 $\left(\mathrm{Fe}^{3+} / \mathrm{SCN}^{-}\right.$モル比) 50〜500 亿拈いて生成し， これを $\mathrm{Hg}_{2}{ }^{2+}$ 溶液により直接滴定する。 $\mathrm{HNO}_{3}$ 酸性度が高い時 には錯塩が安定となり，還元が定量的に進まず，また錯塩生成後 これを放置 (30 分以上) する時には錯塩は安定となり，正俱差 を与える。 $\mathrm{Fe}^{3+} / \mathrm{SCN}^{-}$モル比が 50 以下の場合には負誤差を与 光る。 $\mathrm{Cu}^{2+}, \mathrm{Co}^{2+}$ の共存はゆるされないが， $\mathrm{Fe}^{3+}$ と錯塩を生 成する $\mathrm{F}^{-}, \mathrm{P}_{2} \mathrm{O}_{7} 4^{-}, \mathrm{C}_{4} \mathrm{H}_{4} \mathrm{O}_{8}{ }^{2-}$ 等の共存はあまり多量 $(25 \mathrm{mg})$ でなければさしつかえない。 $\mathrm{Fe}^{3+}$ 1 10 mg の定量に好適であ る。

$\mathrm{Cu}^{2+}$ の定量。 $\mathrm{Fe}^{3+}$ の場合同様 $\mathrm{SCN}^{-}$を共存させることによ ってはじめて還元反応 $\left(\mathrm{Cu}^{2+}+\mathrm{Hg}_{2}{ }^{2+} \rightleftharpoons \mathrm{Cu}^{+}+\mathrm{Hg}^{2+}\right)$ が進み， CuSCN が生成してくる。この直接谪定の終点は $\mathrm{Cu}^{2+}$ とベンジ ジンとの呈色（淡青色）が袙色するところとした。この呈色はべ ンジジンよりその誘導体であるオルトジアニシジンが最も鮮明で, この呈色は $\mathrm{pH} 4.4$ 以上でみられる。 $\mathrm{SCN}^{-}$共存時の還元反応は $\mathrm{SCN}^{-}$濃度が高い時には定量的に進まず裉色が早く起る。 $\mathrm{SCN}^{-}$ 湄度は $\mathrm{KSCN}$ 0.25 0.4 M に保つとよい。 $\mathrm{Cu}^{2+} 10 \mathrm{mg}$ 以下の 場合汇は袏色がみにくい。C $\mathrm{Cu}^{2+} 10 \sim 20 \mathrm{mg}$ の定量に好適である。 Belcher $は \mathrm{Cu}^{2+}+\mathrm{Fe}^{2+} \rightleftharpoons \mathrm{Fe}^{3+}+\mathrm{Cu}^{+}$の反応基き生成した $\mathrm{Fe}^{3+}$ 飞 $\mathrm{SCN}^{-}$を共存させて $\left[\mathrm{Fe}(\mathrm{SCN})_{6}\right] n^{n-3}$ を生成し, この 錯塩を $\mathrm{Hg}_{2}{ }^{2+}$ 溶液で滴定し $\mathrm{Fe}^{3+}$ を定量して $\mathrm{Cu}^{2+}$ を間接的に 定量した。この Belcher 法の追試実験の結果を併記した。

(昭和 29 年 11 月, 分析学会第 3 年会(於布施)扰 上び昭和 30 年 5 月東北支部常会（於仙台）で償）

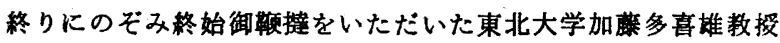
飞感謝致します。本実験の一部は昭和 28 年度文部省科学研究助 成補助金により行った。 